\title{
SELF-REGULATED LEARNING WITH A MODULE TO IMPROVE LEARNING ACHIEVEMENT
}

\author{
Ikhwanuddin', Sumarjo H², V. Lilik Hariyanto ${ }^{3}$, and A. Hasan ${ }^{4}$ \\ ${ }^{123}$ Department of Civil Engineering and Planning Education, Faculty of Engineering, Universitas Negeri Yogyakarta, \\ Indonesia; ${ }^{4}$ Faculty of Technical and Vocational Education, Universitas Tun Hussein Onn Malaysia, Malaysia \\ E-mail: ikhwanuddin@uny.ac.id
}

\begin{abstract}
Drafting competence using Computer Aided Design (CAD) is required for building projects. The basic competence of CAD courses is students can draw elevation houses with CAD. To improve the effectiveness of learning, it has been developed a CAD learning module. This study was aimed to identify the utilization strategy of the CAD learning module to improve self-regulated learning. It is believed that increasing self-regulated learning can improve learning achievement. This research method consisted of four cycles: plan, action, observation, and reflection. The data were in the form of quantitative and qualitative data. Data collecting techniques were observation and documentation. Data analysis techniques used mean scores and reflection. The target was the mean score of classical tasks which is bigger than 80 in high difficult tasks. The results of the study were (1) there were differences in learning achievement in applying the concept of self-regulated learning with a collaborative approach and an individualistic approach, (2) self-regulated learning concepts with collaborative approach is more appropriate for the CAD module-based learning, and (3) the concept selfregulated learning with collaborative approach can improve learning achievement.
\end{abstract}

Keywords: learning module, learning achievement, self-regulated learning

\section{INTRODUCTION}

The free labor market for ASEAN, which began to take shape in 2015 , leads to the high labor competition. Indonesian workers have a tremendous opportunity to utilize the increasingly open employment since Indonesia is $43 \%$ of ASEAN total population with the labor number of 125.3 million people in 2014 . Thus, improving the quality of human resources is a crucial factor to succeed in passing through the free flow of labor.

The current issues in Indonesia related to the ASEAN labor market are the trend of an increasing number of well-educated unemployment caused by the mismatch between graduates' competence and market needs. If they do not meet the criteria of domestic labor needs, then it will be difficult for Indonesian labor to compete in the ASEAN market. It is certainly a real challenge for universities, especially vocational education, to revitalize the education system and its learning process. ASEAN Economic Community (AEC) pave the way for the free flow of skilled labor in eight professions, namely engineers, architects, nurses, surveyors, tourism practitioners, medical practitioners, dentists, and accountants. The professionals related to architects and engineers are drafters. They should also improve their skills in order to assist both professions in the projects from domestic and foreign contractors.

As a drafter, the ability to use building drawing application software currently becomes necessary competence. With the use of Computer-Aided Design (CAD), the process of drawing, changing, printing, and distributing building drawing is faster. The expected learning outcomes for CAD courses in the Study Program of Civil Engineering and Planning in Faculty of Engineering, Universitas Negeri Yogyakarta, is the students can design a pre-plan of a one-floor house. The learning module for CAD has already developed to improve students' self-regulated learning. Therefore, it is necessary to examine the utilization strategy of CAD learning module. Since self-regulated learning is a reliable predictor of academic success [1], [2]. 


\section{METHOD}

This study was a classroom action research, i.e., participatory research based on problems that arise from real learning problems (real-life learning problems). The design of this classroom action research was based on the Kemmis \& Taggart model which procedure consisted of four repetitive stages, starting from planning, implementing actions, observation and reflection [3].

The first stage is planning conducted with preparing learning modules according to the number of students, preparing research instruments for data collection, and coordinating with the observers. The second stage was the action stage by implementing the learning plans. The module-assisted learning plans were used in the classroom to achieve learning objectives and to enhance selfregulated learning. The third stage was the observation that included a systematic observation and data collection on students' activities during their learning. Data collection was done through observation without disturbing the learning process. The data consisted of self-regulated learning and completion time of drawing assignments.

Meanwhile, the drawing assignment data was documented in each students' computer. The last stage is a reflection to understand the meaning or reason behind the data change after the process of data analysis. Although the reflection process was very subjective, the results of reflection must be logicalargumentative. Reflection was the most critical point in classroom action research because it determined the sustainability of the research cycle. Reflection activities had to find substantial problems and produce appropriate recommendations for the next cycle.

Data collection techniques used systematic observation with checklist and documentation of CAD course assignments. The documentation of drawing assignments was in the form of CAD files on each student computer. The data were in the form of drawing learning outcomes, self-regulated learning, and tasks completion.

\section{RESULTS AND DISCUSSION}

This classroom action research was aimed to improve students' self-regulated learning. For the beginning, it was used the concept of individualistic self-regulated learning based on the domain concept in selfregulated learning theories. In the pre-cycle, students were given learning modules I, II and III to learn and to practice. The learning module was prepared to step by step to produce a guided drawing practice. Next, the students were asked to work on self-regulated learning tasks with drawing object that was similar to guided drawing assignments. At the end of the cycle, both assignments were evaluated and the completion time was recorded. Learning outcomes in the pre-cycle were as follows:

Table 1. The Mean of Pre-Cycle Score Variable

\begin{tabular}{ccccc}
\hline Module & \multicolumn{4}{c}{ Variable (\%) } \\
& A & B & C & D \\
\hline Module II & 90.0 & 96.3 & 98.0 & 96.7 \\
Module III & 95.0 & 96.0 & 98.2 & 96.7 \\
Total & 185.0 & 192.3 & 196.2 & 193.3 \\
Mean & 92.5 & 96.2 & 98.1 & 96.7 \\
\hline Where & \multicolumn{4}{|}{} \\
Variable A & : self-regulated learning \\
Variable B & : Task for drawing practice \\
Variable C & : Task for self-regulated learning \\
Variable D & : Time completion
\end{tabular}

The second module was the procedure for setting AutoCAD screen based on the size of the drawing object. The third module contained procedures to draw Roster objects. The high score of all variables in the Pre-Cycle only showed the ease of task in this cycle. In the first cycle of the study, modules 1 and 5 were given. Each module was a guide to draw elevation and floor plans for doors and windows. At the beginning of the cycle, the students were reminded to work without the assistance from their peers during the learning process. In the fourth and fifth modules, there was guided drawing training and self-regulated 
learning. The action plan for the cycle I was as follows: (1) preparing module-based learning scenarios, (2) checking computer readiness for CAD learning, (3) preparing observation sheets, (4) coordinating with the observers.

The following were the actions taken in the first cycle: (1) the lecturers showed the learning objectives at the beginning of the cycle, and reminded students that they could study the learning module independently, (3) the students follow the learning module instructions according to their abilities, and (4) the lecturers ended learning activities after the learning time was over.

The results of observations during the learning process using the 4th and 5th modules were as follows: (1) In the drawing exercise stage, four students still asked each other about the work steps in the module, (2) In the independent exercises, some students asked each other about the dimensions of doors and windows to ensure the reference size, and (3) some students were relatively slow in following the module instructions. The observation results in the cycle 1 presented in Table 2.

Table 2. The Mean Score of Cycle I Variable

\begin{tabular}{ccccc}
\hline Module & \multicolumn{4}{c}{ Variable } \\
& $\mathrm{A}$ & $\mathrm{B}$ & $\mathrm{C}$ & $\mathrm{D}$ \\
\hline IV & $95.0 \%$ & $96.3 \%$ & $87.0 \%$ & $85.8 \%$ \\
$\mathrm{~V}$ & $95.0 \%$ & $94.7 \%$ & $87.0 \%$ & $91.7 \%$ \\
Total & $190.0 \%$ & $190.7 \%$ & $174.0 \%$ & $177.5 \%$ \\
Mean & $95.0 \%$ & $95.3 \%$ & $87.0 \%$ & $88.8 \%$ \\
\hline
\end{tabular}

In the reflection stage, the variables comparison results between the two cycles produce interesting temporary findings to be followed up in the next cycle. The comparison of mean variable scores in the pre-cycle and the first cycle can be seen in Table 3 below. Figure 2 was presented to clarify the mean change in the variable score between the two cycles. Figure 2 shows that the self-regulated learning of research subjects (variable A) rose from $92.5 \%$ to $95.0 \%$. Meanwhile, learning outcomes using modules (variable B) decreased a little point, i.e., $0.9 \%$, from $96.2 \%$ to $95.3 \%$. It can be concluded that the learning module can helm the research subjects to achieve the competence in a guided drawing exercise.

Table 3. The Variable Score Comparison between PreCycle and Cycle I

\begin{tabular}{lcccc}
\hline \multirow{2}{*}{ Cycle } & \multicolumn{4}{c}{ Variable (\%) } \\
& A & B & C & D \\
\hline Pre-cycle & 92.5 & 96.2 & 98.1 & 96.7 \\
cycle I & 95.0 & 95.3 & 87.0 & 88.8 \\
\hline
\end{tabular}

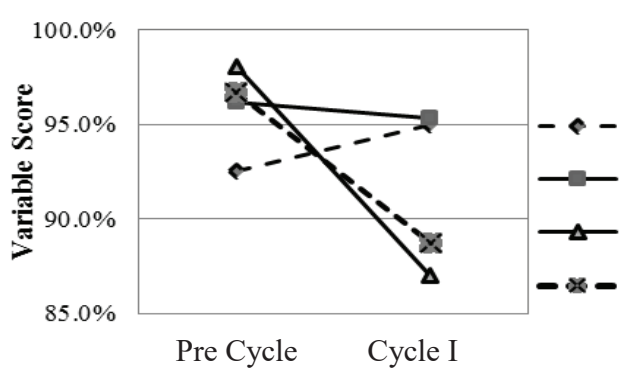

Figure 2. Comparison of Variable Score between Pre-Cycle and Cycle I

In contrast to the results of guided training, there was a substantial decrease in independent tasks of $11.1 \%$, from $98.1 \%$ to $87.0 \%$. It was assumed to be caused by the higher difficulty of the drawing object in the first cycle. Variable D decreased by $7.9 \%$, from $96.7 \%$ to $88.8 \%$. The score of completion of this task supports the assumption that the difficulty level of the drawing object in the first cycle was higher than in the pre-cycle.

The reflections from that case were as follows: (1) Did the effort to increase individual self-regulated learning by $2.5 \%$ in this first cycle negatively affect the results of guided drawing learning? It cannot be ascertained yet because there were other factors that had an effect, namely the difficulty of the drawing object, (2) The score decrease on the completion of guided assignments and training assignments (variable of D), support the assumption in case of the difficulty level of the task as the cause, (3) Several research subjects was still asking their peers with the varied effect in which some students were stagnant and other can improve learning achievement, 
(4) In general, there was a decrease in the mean score of self-regulated training tasks. This also may be caused by two things, a lack of knowledge about the size of the drawing object, and lack of thoroughness in reading the module instructions.

From the above reflection, there were several recommendations proposed to improve the next research cycle, they were: (1) at the beginning of the cycle, the research subject should be reminded to be more thorough in reading the learning module, (2) Before learning began, it was necessary to explain the general dimensions of drawing object.

The action plan in the second cycle was generally similar to the action plan in the first cycle. There were only two actions added based on a recommendation in the first cycle. The following were the actions taken in the first cycle, (1) lecturers explained about the skills to be studied, (2) lecturers explained the elements and standard dimensions of drawing object, (3) students learned and followed the drawing procedure on the module, (4) students continued the drawing assignments independently in the form of floor plans for 2 to 3 students.

The results of observations in this second cycle were as follows: (1) the lecturer explained the basic elements and the standard dimensions of the floor plan, (2) after the question and answer session, students used the learning module to complete guided tasks, (3) the selfregulated assignments were conducted afterward the guided tasks. The observations results of cycle II is presented in Table 4.

Table 4. The Mean of Variable Score for Cycle II

\begin{tabular}{ccccc}
\hline \multirow{2}{*}{ Module } & \multicolumn{4}{c}{ Variable (\%) } \\
& $\mathrm{A}$ & $\mathrm{B}$ & $\mathrm{C}$ & $\mathrm{D}$ \\
\hline Module VI & 100.0 & 92.7 & 82.7 & 94.2 \\
Module VII & 100.0 & 89.3 & 82.7 & 85.8 \\
Total & 200.0 & 182.0 & $165.3 \%$ & 180.0 \\
Mean & 100.0 & 91.0 & 82.7 & 90.0 \\
\hline
\end{tabular}

The purpose of reflection was to find out the main causes of the declining learning achievement as found in the first cycle. The comparison of research variables between the first and second cycles can be seen in Table 6 . Based on Table 5, the comparison of the variable score for cycle I and II is formulated in Figure 3.

Table 5. Variable scores for cycle I and II

\begin{tabular}{ccccc}
\hline \multirow{2}{*}{ Cycle } & \multicolumn{4}{c}{ Variable (\%) } \\
& A & B & C & D \\
\hline Cycle I & 95.0 & 95.3 & 87.0 & 88.8 \\
Cycle II & 100.0 & 91.0 & 82.7 & 90.0 \\
\hline
\end{tabular}

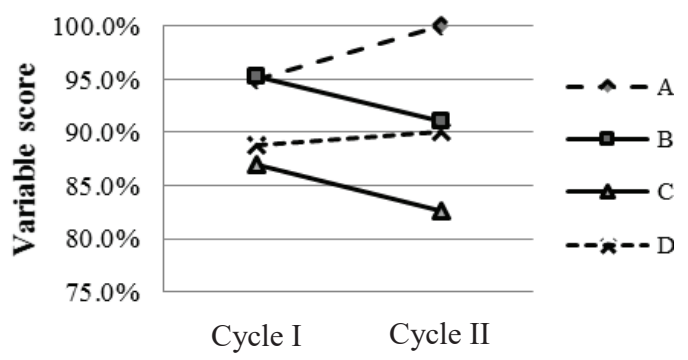

Figure 3. The Comparison of Variable Score for Cycle I and II

It can be seen that the escalation of selfregulated learning on the research subjects (variable of A) from $95 \%$ to $100.0 \%$. Meanwhile, the learning outcomes using modules (variable of $\mathrm{B}$ ) was declining $4.3 \%$, from $95.3 \%$ to $91.0 \%$. The escalation of the score of the variable of A was followed by the declining in the variable score of B with the same relative degree. It was a very interesting thing to be reflected seriously. Moreover, in the two previous cycles in a row, the escalation in the score of self-regulated learning was precisely followed by the declining in the score of guided learning outcomes (variable of B). Thus, the declining in the score of the variable of B in two cycles respectively should be no longer considered due to the differences in the difficulty level of the drawing object.

It was also interesting to observe the decreasing trend on the score of the variable of $\mathrm{B}$ and C. If the variable of B dropped by $4.3 \%$, then the variable $\mathrm{C}$ also decreased $4.3 \%$, from $87.0 \%$ to $82.7 \%$. The decline in variables of $\mathrm{B}$ and $\mathrm{C}$ with the same degree from the first and second cycles led to the emergence of the 
assumption that the attempts to increase individualistic self-regulated learning had become the main cause of the learning outcomes decline. The decrease in the variable of $\mathrm{D}$ score was $1.2 \%$, from $88.8 \%$ to $90.0 \%$ and it can be considered as the impact from the efforts to improve the learning process using the learning module by giving a theoretical explanation at the beginning of the cycle.

The concept of individualistic selfregulated learning emphasizes the responsibility of learning without the assistance from others. This concept considers one assistance as an indication of the lack of independence of individual learning. Therefore, it is necessary to apply the concept of collective independence learning which emphasizes more on the learning responsibility, not on without any help from others.

From the above reflections, there were several recommendations that can be given to improve learning in the next cycle, namely: (1) at the beginning of the cycle, a theoretical explanation of the drawing object was given in to suppress the difficulty level of drawing object, and (2) the need for the application of the concept of collective independence learning in the next cycle.

In the third cycle, the eighth and ninth modules were used. This module contained guidelines to give shading lines to drawing object of columns, brickwork, and ceramic patterns. Meanwhile, the ninth module covered guideline to insert pictures of furniture from the library, names of spaces giving, floor height, space size, and line arrangement. The action plan for this third cycle was to develop learning scenarios according to the recommendations in the second cycle. The following were the actions taken in the third cycle: (1) explanation on the studied skills, (2) explanation of the floor plan elements according to the needs of the eighth module, (3) the students allowed to ask each other to understand the drawing procedure, (4) students drew according to procedures and instructions in the eighth module.
The results of action observations in this third cycle were as follows: (1) after the learning objectives were delivered, the lecturer explained the notation of brickwork shading, columns, ceramics, floor height, and the provision of space and land dimensions, (2) after question and answer session, the lecturer invited students to discuss procedures and drawing tasks in the module, and (3) students completed the eighth and ninth module. The observations results of the research variables in the third cycle are presented in Table 6 . Furthermore, the comparison of research variable scores between the second and third cycles can be seen in Table 7 .

Table 6. Mean of the variable score in cycle III

\begin{tabular}{lcccc}
\hline \multirow{2}{*}{ Module } & \multicolumn{4}{c}{ Variable (\%) } \\
& A & B & C & D \\
\hline Module VIII & 90.0 & 93.7 & 86.7 & 95.8 \\
Module IX & 90.0 & 90.3 & 85.3 & 78.3 \\
Total & 180.0 & 184.0 & 172.0 & 174.2 \\
Mean & 90.0 & 92.0 & 86.0 & 87.1 \\
\hline
\end{tabular}

Table 7. The Comparison of Research Variable Scores Between the Second and Third Cycles

\begin{tabular}{ccccc}
\hline \multirow{2}{*}{ Cycle } & \multicolumn{4}{c}{ Variable (\%) } \\
& A & B & C & D \\
\hline Cycle II & 100.0 & 91.0 & 82.7 & 90.0 \\
Cycle III & 90.0 & 92.0 & 86.0 & 87.1 \\
\hline
\end{tabular}

Figure 4. The Comparison of Variable Scores between the Second and Third Cycles

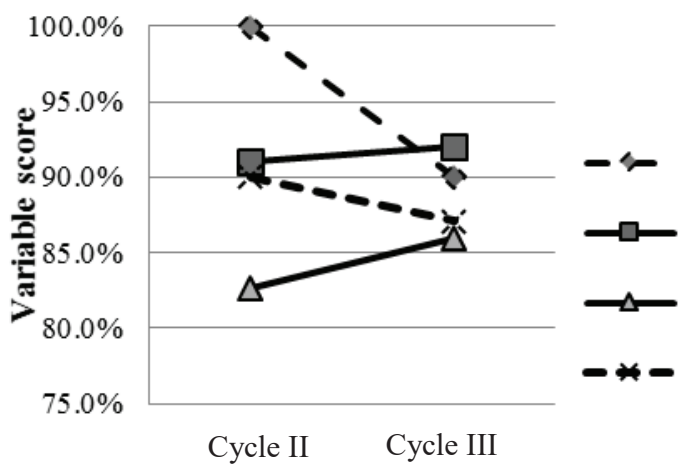

The graph above showed that the score of self-regulated learning the research subjects (variable of A) declined noticeably by $10 \%$, from $100 \%$ to $90.0 \%$ and learning outcomes 
with modules (variable B) only increased by $1.0 \%$, from $92.0 \%$ to $93.0 \%$. The Decrease of the variable of A score was followed by the escalation of the score from the variable of $\mathrm{B}$. Although the increase in the score of variable B was still minimal, it raised the assumption that the influence of collective self-regulated learning was positive. Conversely, the concept of "individualistic self-regulated learning" was the cause of the decline in learning outcomes in the previous cycle. The escalation trend of $\mathrm{C}$ variable mean score was $3.3 \%$, i.e., $82.7 \%$ to $86.0 \%$, along with the increase in the variable of B was quite surprising. In general, if there was an increase, the score of the training task was higher than the independent task, but in this study showed the contrary.

The difficulty level of the drawing object in the third cycle was lower than the second cycle. Learning collaboration affected learning comprehension towards the learning module. Learning collaboration showed an increase in collective self-regulated learning. Therefore, it was necessary to have more explicit actions in the application of collective learning concept.

Based the reflections above, the recommendations for next cycle were: (1) at the beginning of the cycle, a theoretical explanation of the drawing object was given to reduce the difficulty level, (2) the importance of collective self-regulated learning and its application need to be explained to the students. In the fourth cycle, the tenth module was used. This module contained a drawing guideline of buildings based on plans that had been made in the previous cycle. Knowledge, skills, and creativity were indispensable to draw the elevation of the building. Action plan in the fourth cycle was to arrange the learning scenario based on the module by referring to the recommendation of the third cycle.The following were the actions of the fourth cycle, (1) lecturer's explanation of the learning goals,
(2) explanation on the picture elements to draw the building, (3) explanation on the importance of collective self-regulated learning to succeed the learning and its implementation in drawing learning, and (4) the students completed the elevation drawing on guided tasks and independent tasks.

Observation in this fourth cycle is to continue the elevation drawing based on the drawing plan that was done in the previous cycle. The results of observations in this fourth cycle were as follows: (1) after opening the lesson, the lecturer explained the learning goals and the elements of elevation design including: models of doors, windows, rosters, tile shading and ridge, (2) explaining the standard dimensions of the picture, (3) explaining the importance of collective self-regulated learning, and allowing students to discuss the drawing procedures that were not yet understood, and (4) many students exchanged drawings and discussed the drawing techniques. The observations result in the fourth cycle is presented in Table 8 .

Table 8. Variable score in cycle IV

\begin{tabular}{lccccc}
\hline \multicolumn{1}{c}{ Module } & \multicolumn{5}{c}{ Variabel (\%) } \\
& $\mathrm{A}$ & $\mathrm{B}$ & $\mathrm{C}$ & $\mathrm{D}$ \\
\hline $\begin{array}{l}\text { Indicator } \\
\text { score of } \\
\text { module }\end{array}$ & $73.3 \%$ & $92.3 \%$ & $85.7 \%$ & $80.00 \%$ \\
\hline
\end{tabular}

Based on the observation data above, it needs to be revealed the influence of the concept of collective self-regulated learning which was more explicit in the drawing learning outcomes. The comparison of the research variables scores in the third and fourth cycles can be seen in Table 9 below.

Table 9. The Comparison of the Research Variables Scores In the Third and Fourth Cycles

\begin{tabular}{ccccc}
\hline \multirow{2}{*}{ Cycle } & \multicolumn{4}{c}{ Variable (\%) } \\
& $\mathrm{A}$ & $\mathrm{B}$ & $\mathrm{C}$ & $\mathrm{D}$ \\
\hline Cycle III & 90.0 & 92.0 & 86.0 & 87.1 \\
Cycle IV & 73.3 & 92.3 & 85.7 & 80.0 \\
\hline
\end{tabular}




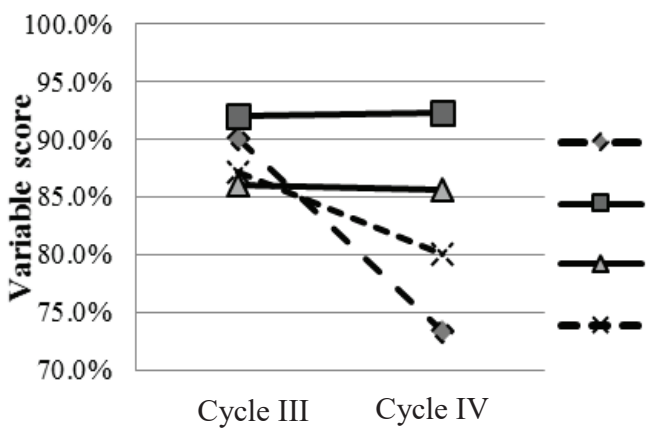

Figure 5. The Change of Variable Score from Cycle III and IV

Based on the graph above, it can be seen that the score of individualistic self-regulated learning of research subjects (variable of A) dropped significantly by $16.7 \%$, from $90 \%$ to $73.3 \%$. It meant that collective self-regulated learning was increasing. Meanwhile, the learning outcomes using modules (variable of B) only was increased by $0.3 \%$, from $92.0 \%$ to $92.3 \%$. Although the escalation had not met the expectation, the increase in the score of the guided drawing task had provided a positive indication of the effect of collective selfregulated learning.

The decrease of the mean score for the $\mathrm{C}$ variable (independent assignment) was $0.3 \%$, from $86.0 \%$ to $85.7 \%$, and it was not expected. However, the decline in the variable of $\mathrm{D}$ (the mean of completion time) was $7.1 \%$, from $87.1 \%$ to $80.0 \%$ showing the difficulty level of the task was higher. However, independent task learning achievement increased and independent task was stagnant.

Based on the above reflection, it can be concluded that the target of research is in the form of learning achievement mean of drawing guided assignments and independent assignments that has achieved $85.7 \%$, it was above the target of $81 \%$. The fourth cycles showed that the concept of collective selfregulated learning could have a positive influence on the improvement of drawing learning achievement.

Referring to linguistics aspects, independence or self-regulated is defined as something or the situation to stand alone without relying on others [4]. According to Darajat, in Ulomo [5], learning independence is defined as the tendency of students to do something they want without help from others.

From a psychological point of view, it is defined as the level of one's development in which he/she can rely on his/her ability to decide and carry out various activities without the help of others [6]. In line with this, Bandura clarifies self-regulated learning as the ability to manage themselves, the ability to know and how students protect themselves from the distraction that disrupts the learning process [7]. Here, independence or autonomy is defined as the ability to manage and protect self from learning barriers.

Some point of views on self-regulated learning also emphasizes the readiness or ability of individuals to learn without any assistance from others [8][9]. Self-regulated learners can plan their learning activities before the task begin [1]. In this view, learning was contrasted from teacher-oriented learning or others into self-directed [1]. Other concepts of selfregulated learning that do not emphasize on "solitude" in learning, such as Laird who stated that the characteristics of self-regulated learning are the ability to exchange experiences with other students [10]. In line with this, selfregulated learning is the nature, attitude and ability to conduct learning activities on their own or with help from others based on their motivation to master certain competencies [11].

The level of self-regulated learning is grouped into two, high and low. Students at high self-regulated learner have a characteristic of committed to task completion and can exchange ideas and information with others, to collaborate for tasks completion, and to find help from friends or teachers [7]. It means the most fundamental concept of self-regulated learning is emphasized on the students' responsibility or learning commitment not on their ability to direct themselves to learn without any help from others.

Learning achievement is the evidence of students ability in conducting their learning [12] 
[13][14][15]. This research aims at finding the appropriate concept of self-regulated learning for module-based learning because it is a crucial factor to improve learning achievement. The application of the concept of individualistic and collective self-regulated learning in the cycle of this research can be seen in Table 10.

Table 10. The Comparison of Variable Score of Pre-Cycle till Cycle IV

\begin{tabular}{ccccc}
\hline Cycle & \multicolumn{4}{c}{ Variable } \\
& $\mathrm{A}$ & $\mathrm{B}$ & $\mathrm{C}$ & $\mathrm{D}$ \\
\hline Pre & $92.5 \%$ & $96.2 \%$ & $98.1 \%$ & $96.7 \%$ \\
I & $95.0 \%$ & $95.3 \%$ & $87.0 \%$ & $88.8 \%$ \\
II & $100.0 \%$ & $91.0 \%$ & $82.7 \%$ & $90.0 \%$ \\
III & $90.0 \%$ & $92.0 \%$ & $86.0 \%$ & $87.1 \%$ \\
IV & $73.3 \%$ & $92.3 \%$ & $85.7 \%$ & $80.0 \%$ \\
\hline
\end{tabular}

The score of individualistic self-regulated learning (Variable of A), kept increasing from pre-cycle to the first, and second cycle, by $2.5 \%$, and $5.0 \%$ respectively. Then, the mean score of individualistic self-regulated learning decreased from the second cycle to the third cycle, and fourth, each was $10 \%$ and declined again to $16.7 \%$. The decrease in the score of individualistic self-regulated learning showed an escalation in collective self-regulated learning.

The mean score of guided task (Variable of B) decreased from pre-cycle to the first cycle, and the second cycle, respectively reduced $0.9 \%$ and $4.3 \%$, then increased in the third and fourth cycle by $1 \%$ and $1.3 \%$. A similar pattern occurred in the variable of $\mathrm{C}$ in which declined from pre-cycle to the first cycle, and second, each of them was $11.1 \%$ and decreased again to $4.3 \%$. Then, it raised from the second cycle to the third cycle by $3.3 \%$ but then dropped to $0.3 \%$.

The pattern variable of $\mathrm{D}$ follows the pattern of A variables and B variable. It tends to rise and to fall in its declining pattern. It seems that $\mathrm{D}$ variable pattern is related to the difficulty level of the drawing task that getting higher. The concept of self-regulated in pre-cycle until the second cycle used an individualistic approach which emphasized the ability of oneself without the help from others. Meanwhile, the third and four cycle concepts were using a collaborative approach.

The quality of guided drawing assignments and self-regulated exercise in precycle until the second cycle were in the form of an opposite pattern with the increase of the individualistic self-regulated learning concept. Meanwhile, the quality of guided drawing assignments and self-regulated task in the third and fourth cycles followed the parallel pattern with the indicators increase of the concept of collaborative self-regulated learning. The whole pattern can be seen in Figure 6.

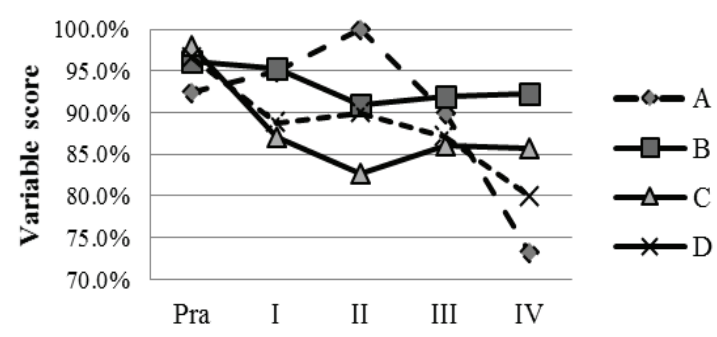

Figure 6. The Pattern of Variable among the Research Cycles

\section{CONCLUSION}

CAD learning module can improve selfregulated learning through a collaborative approach. Increasing the collaborative selfregulated learning can improve the achievement of learning in drawing. Furthermore, utilization of modules as an effort to improve collaborative self-regulated learning is by giving an introduction to the theory on the elements of drawing object and its dimensions and emphasizing the importance of accuracy and thoroughness in self-regulated drawing tasks.

\section{REFERENCES}

[1] S. M. M. Loyens, J. Magda, and R. M. J. P. Rikers, "Self-Directed Learning in Problem-Based Learning and its Relationships with Self-Regulated Learning," Educ. Psychol. Rev., vol. 20, no. 4, pp. 411-427, Dec. 2008. 
[2] F. A. R. Director and J. A. Rafferty, "Instructional Design Interventions for Supporting Self-Regulated Learning: Enhancing Academic Outcomes in Postsecondary E-Learning Environments," MERLOT J. Online Learn. Teach., vol. 9, no. 4, pp. 590601, 2013.

[3] S. Madya, Teori dan Praktik Penelitian Tindakan Kelas (Action Research). Bandung: Alfabeta, 2009.

[4] Department of National Education, Kamus Besar Bahasa Indonesia Pusat Bahasa. Jakarta: Gramedia Pustaka Utama, 2008.

[5] C. Ulomo, "Hubungan Kefektifan Mengikuti Kegiatan Ekstrakurikuler Pramuka dan Perhatian Orang tua dengan Kemandirian Belajar Siswa di SD 1 Colo kecamatan dawe Kab. Kudus," Universitas Sebelas Maret Surakarta, 2015.

[6] U. Widowati, "Tingkat Kemandirian Pilihan Karir Siswa SMK," Universitas Sanata Dharma, 2016.

[7] A. Tjalla and E. Sofiah, "Peer reviewed PDF on ERIC Download Full Text ERIC Number: EJ1079031 Record Type: Journal Publication Date: 2015 Pages: 7 Abstractor: As Provided Reference Count: 18 ISBN: N/A ISSN: ISSN-2222-1735 Effect of Methods of Learning and Self Regulated Learning toward Outcomes of Learning Social Studies," J. Educ. Pract., vol. 6, no. 23, pp. 15-20, 2015.

[8] S. Ahmadi, S. Khanagha, L. Berchicci, and J. J. P. Jansen, "Are Managers Motivated to Explore in the Face of a
New Technological Change? The Role of Regulatory Focus , Fit , and Complexity of Decision-Making," no. March, 2017.

[9] F. Wastono, "Peningkatan Kemandirian Belajar Siswa SMK pada Mata Diklat Teknologi Mekanik dengan Metode Problem Based Learning," J. Pendidik. Teknol. dan Kejuru., vol. 22, no. 4, pp. 396-400, Jan. 2016.

[10] F. Agus, "Pengaruh Kemandirian Belajar dan Persepsi Tentang Kompetensi Guru terhadap Prestasi Belajar IPS Siswa Kelas VIII SMP N2 Patuk TA 2012/2013,” Universitas Negeri Yogyakarta, 2013.

[11] Suparman, "Peningkatan Kemandirian Belajar dan Minat Belajar Mahasiswa Mata Kuliah Elektronika Analog dengan Pembelajaran PBL," J. Pendidik. Teknol. dan Kejuru., vol. 22, no. 1, pp. 83-88, 2014.

[12] D. Ardhini, "Hubungan Motivasi Berprestasi dan Kepercayaan Diri dengan Prestasi Siswa Kelas Olaharga SMP Negeri 4 Purbalingga.," Universitas Negeri Yogyakarta, 2012.

[13] W. S. Winkel, Psikologi Pengajaran. Jakarta: Grsindo, 1996.

[14] E. Nauli Thaib, "Hubungan antara Prestasi Belajar dengan Kecerdasan Emosional," J. Ilm. Didakt., vol. 13, no. 2, pp. 384-399, Feb. 2013.

[15] E. Mulyadi, "Penerapan Model Project Based Learning untuk Meningkatan Kinerja dan Prestasi Belajar Fisika Siswa SMK," J. Pendidik. Teknol. dan Kejuru., vol. 22, no. 4, pp. 385-395, Jan. 2016. 